\title{
A Triterpene and a Depside from Parmotrema austrocetratum Elix and J. Johnst.
}

\author{
Consolacion Y. Ragasa ${ }^{1,2, *}$, Maria Carmen S. Tan' ${ }^{1}$, Virgilio C. Linis ${ }^{3}$, Chien-Chang Shen ${ }^{4}$
}

\section{Consolacion Y. Ragasa ${ }^{1,2, *}$, Maria Carmen S. Tan', Virgilio C. Linis ${ }^{3}$, Chien-Chang Shen ${ }^{4}$}

\author{
'Department of Chemistry, De La Salle \\ University, 2401 Taft Avenue, Manila \\ 1004, PHILIPPINES. \\ ${ }^{2}$ Chemistry Department, De La Salle \\ University Science and Technology \\ Complex Leandro V. Locsin Campus, \\ Biñan City, Laguna 4024, PHILIPPINES. \\ ${ }^{3}$ Department of Biology, De La Salle \\ University, 2401 Taft Avenue, \\ Manila 1004, PHILIPPINES. \\ ${ }^{4}$ National Research Institute of Chinese \\ Medicine, Ministry of Health and \\ Welfare, 155-1, Li-Nong St., Sec. 2, \\ Taipei, TAIWAN. \\ Correspondence \\ Consolacion Y. Ragasa \\ Department of Chemistry, De La Salle \\ University, 2401 Taft Avenue, \\ Manila 1004, PHILIPPINES. \\ Phone no: +63-2-5360230 \\ E-mail: consolacion.ragasa@dlsu.edu.ph \\ History \\ - Submission Date: 24-07-2018; \\ - Review completed: 25-08-2018; \\ - Accepted Date: 05-09-2018
}

DOI : $10.5530 / p j .2018 .6 s .4$

Article Available online http://www.phcogj.com/v10/i6s

\section{Copyright}

(C) 2018 Phcog.Net. This is an openaccess article distributed under the terms of the Creative Commons Attribution 4.0 International license.

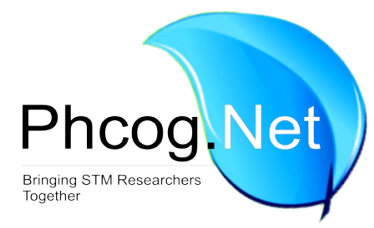

\begin{abstract}
Introduction: Parmotrema austrocetratum Elix and J. Johnst. (syn. Rimelia austrocetrata Elix and J. Johnst.) which belongs to a large genus of lichenized fungi, Parmotrema Massalongo under family Parmeliaceae was investigated for its chemical constituents. Methods: The compounds were isolated by silica gel chromatography and their chemical structures were elucidated by NMR spectroscopy. Results: Chemical investigation of the dichloromethane extract of Parmotrema austrocetratum Elix and J. Johnst. has led to the isolation of zeorin (1) and atranorin (2). Conclusion: P. austrocetratum shares similar chemical characteristic with other Parmotrema species which afforded atranorin. This work highlights the first reported isolation of $\mathbf{1}$ from $P$. austrocetratum and the genus Parmotrema.
\end{abstract}

Key words: Parmotrema austrocetratum, Rimelia austrocetrata, Parmeliaceae, Zeorin, Atranorin.

\section{INTRODUCTION}

Parmotrema austrocetratum Elix and J. Johnst. (syn. Rimelia austrocetrata Elix and J. Johnst.) belongs to a large genus of lichenized fungi under family Parmeliaceae. ${ }^{1}$ Thallus of $P$. austrocetratum are loosely adnate with broad, rotund lobe apices. The upper surface is reticulately cracked, maculae forming areoles, then eventually flaking off to expose the medulla. Erhizinate marginal in the lower cortex are either absent or very narrow. Lower cortex generally black with brown marginal area Soredia are absent. Marginal cilia frequent while rhizines are simple to squarrose and black in color. ${ }^{1}$ Its genus name Parmotrema refers to the perforate apothecia (Greek parmos = cup and trema $=$ perforation $).{ }^{2}$ In the Philippines, $P$. austrocetratum is distributed in Northern Cordillera in Luzon island and Mount Apo in Mindanao island..$^{3-4}$ The Philippine specimen chosen for our chemical investigation was gathered from the trunk of a Benguet pine (Pinus kesiya Royle ex Gordon) in Camp John Hay, Baguio City.

Parmotrema austrocetratum was reported to contain atranorin and salazinic acid. ${ }^{1}$ Of relevance to our present report are several studies on the genus Parmotrema which reported the presence of atranorin in $P$. arnoldii, ${ }^{5}$ P. crinitum,${ }^{5}$ P. perlatum, ${ }^{5}$ P. stuppeum,${ }^{5}$ P. crocoides,${ }^{6}$ P. dilatatum, ${ }^{6}$ P. eciliatum, ${ }^{6}$ P. endosulphureum, ${ }^{6}$ P. erubescens, ${ }^{6}$ P. flavescens, ${ }^{6}$ P. flavomedullosum, ${ }^{6}$ P. gardner $i,{ }^{6}$ P. latissimum, ${ }^{6}$ P. eucosemothetum, ${ }^{6}$ P. masonii, ${ }^{6}$ P. mellissii, ${ }^{6}$ P. neotropicum, ${ }^{6}$ P. permutatum, ${ }^{6}$ P. robustum, ${ }^{6}$ P. rubifaciens, ${ }^{6}$ P. subarnoldii ${ }^{6}$ P. subisidiosum,,${ }^{6}$ P. subsumptum, ${ }^{6}$ P. wrightii, ${ }^{6}$ P. sancti-angeli, ${ }^{6}$ P. simulans, ${ }^{6}$ P. sorediiferum, ${ }^{6}$ P. soredioaliphaticum, ${ }^{6}$ P. hydrium, ${ }^{7}$ P. praesorediosum, ${ }^{8}$ P. rampoddense, ${ }^{8} \quad$ P. tinctorum $^{8-9} \quad P$. reticulatum ${ }^{8}$
P. negrosorientalum, ${ }^{4}$ P. lichexanthonicum, ${ }^{10}$ P. cetratum, ${ }^{11}$ P. cristiferum, ${ }^{11}$ P. defectum, ${ }^{11}$ P. grayanum, ${ }^{11}$ P. margaritatum, ${ }^{11}$ P. perlatum, ${ }^{11}$ P. pseudocrinitum, ${ }^{11}$ P. reticulatum, ${ }^{11}$ P. subtinctorium. ${ }^{11}$

We report herein the isolation of zeorin (1) and atranorin (2) (Figure 1) from P. austrocetratum. To the best of our knowledge this is the first report on the isolation of $\mathbf{1}$ from $P$. austrocetratum and the genus Parmotrema.

\section{MATERIALS AND METHODS}

\section{General Experimental Procedure}

NMR spectra were recorded on a Varian VNMRS spectrometer in $\mathrm{CDCl}_{3}$ at $600 \mathrm{MHz}$ for ${ }^{1} \mathrm{H} \mathrm{NMR}$ and $150 \mathrm{MHz}$ for ${ }^{13} \mathrm{C}$ NMR spectra. Column chromatography was performed with silica gel 60 (70-230 mesh). Thin layer chromatography was performed with plastic backed plates coated with silica gel $\mathrm{F}_{254}$ and the plates were visualized by spraying with vanillin/ $\mathrm{H}_{2} \mathrm{SO}_{4}$ solution followed by warming.

\section{Sample Collection}

The Philippine specimen chosen for our chemical investigation was gathered from the trunk of a Benguet pine (Pinus kesiya Royle ex Gordon) in Camp John Hay, Baguio City (date of collection: 14 October 2017).

\section{Isolation of the Chemical Constituents of $P$. austrocetratum}

The freeze-dried P. austrocetratum (17.52 g) was ground in a blender, soaked in $\mathrm{CH}_{2} \mathrm{Cl}_{2}$ for three days and then filtered. The filtrate was concentrated under 


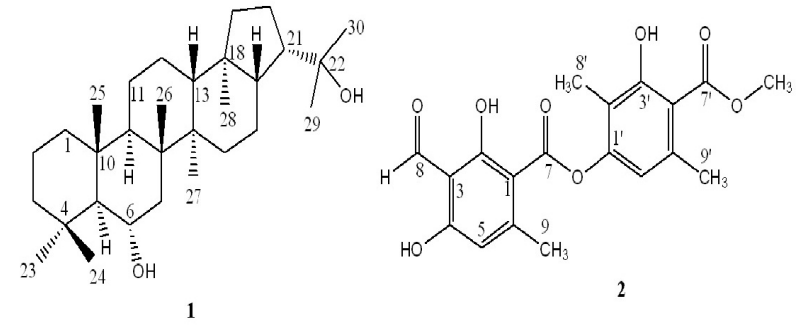

Figure 1: Chemical structures of zeorin (1) and atranorin (2). vacuum to afford a crude extract $(0.1578 \mathrm{~g})$ which was chromatographed by gradient elution using petroleum ether, $2.5 \%$ EtOAc in petroleum ether, 5\% EtOAc in petroleum ether, 7.5\% EtOAc in petroleum ether, $10 \%$ EtOAc in petroleum ether, 12.5\% EtOAc in petroleum ether, 15\% EtOAc in petroleum ether, $\mathrm{CH}_{2} \mathrm{Cl}_{2}, \mathrm{CH}_{3} \mathrm{CN}: \mathrm{Et}_{2} \mathrm{O}: \mathrm{CH}_{2} \mathrm{Cl}_{2}(0.5: 0.5: 9, \mathrm{v} / \mathrm{v})$, $\mathrm{CH}_{3} \mathrm{CN}: \mathrm{Et}_{2} \mathrm{O}: \mathrm{CH}_{2} \mathrm{Cl}_{2}(1: 1: 8, \mathrm{v} / \mathrm{v}), \mathrm{CH}_{3} \mathrm{CN}: \mathrm{Et}_{2} \mathrm{O}: \mathrm{CH}_{2} \mathrm{Cl}_{2}(2: 2: 6, \mathrm{v} / \mathrm{v})$. The $\mathrm{CH}_{3} \mathrm{CN}: \mathrm{Et}_{2} \mathrm{O}: \mathrm{CH}_{2} \mathrm{Cl}_{2}$ (0.5:0.5:9, v/v) fraction was rechromatographed using $15 \%$ EtOAc in petroleum ether, followed by $\mathrm{CH}_{3} \mathrm{CN}: \mathrm{Et}_{2} \mathrm{O}: \mathrm{CH}_{2} \mathrm{Cl}_{2}$ $(0.5: 0.5: 9, \mathrm{v} / \mathrm{v})$. The fractions eluted with $15 \% \mathrm{EtOAc}$ in petroleum ether were combined and rechromatographed using the same solvent to afford 1 ( $4.3 \mathrm{mg}$ ) after washing with petroleum ether. The fractions eluted with $\mathrm{CH}_{3} \mathrm{CN}: \mathrm{Et}_{2} \mathrm{O}: \mathrm{CH}_{2} \mathrm{Cl}_{2}$ (0.5:0.5:9, v/v) were combined and rechromatographed using the same solvent to yield $2(15.1 \mathrm{mg})$ after washing with petroleum ether.

Zeorin (1): ${ }^{1} \mathrm{H} \mathrm{NMR}\left(600 \mathrm{MHz}, \mathrm{CDCl}_{3}\right)$ : $\delta 0.74$ (s, $\left.\mathrm{CH}_{3}-28\right), 0.85\left(\mathrm{~s}, \mathrm{CH}_{3}-25\right)$, 0.96 (s, $\left.\mathrm{CH}_{3}-27\right), 1.00$ (s, $\left.\mathrm{CH}_{3}-26\right), 1.02$ (s, $\left.\mathrm{CH}_{3}-23\right), 1.13$ (s, $\left.\mathrm{CH}_{3}-24\right)$, $1.16,1.19\left(\mathrm{~s}, \mathrm{CH}_{3}-29, \mathrm{CH}_{3}-30\right), 3.94(\mathrm{dt}, J=4.2,10.8 \mathrm{H}-\mathrm{z}) ;{ }^{13} \mathrm{C} \mathrm{NMR}(150$ $\mathrm{MHz}, \mathrm{CDCl}_{3}$ ): $\delta 40.33$ (C-1), 18.50 (C-2), 43.79 (C-3), 33.60 (C-4), 61.07 (C-5), 69.30 (C-6), 45.48 (C-7), 42.85 (C-8), 49.41 (C-9), 39.33 (C-10), 21.03 (C-11), 23.98 (C-12), 49.77 (C-13), 41.86 (C-14), 34.32 (C-15), 21.90 (C-16), 53.94 (C-17), 43.99 (C-18), 41.21 (C-19), 26.58 (C-20), 51.05 (C-21), 73.90 (C-22), 36.73 (C-23), 22.10 (C-24), 17.11 (C-25), 18.25 (C-26), 17.05 (C-27), 16.07 (C-28), 28.75 (C-29), 30.87 (C-30).

Atranorin (2): ${ }^{1} \mathrm{H} \mathrm{NMR}\left(600 \mathrm{MHz}, \mathrm{CDCl}_{3}\right): \delta 6.38$ (s, H-5), $10.34(\mathrm{~s}, \mathrm{H}-8)$, 2.67 (s, $\left.\mathrm{CH}_{3}-9\right), 6.50$ (s, H-6'), 2.07 (s, $\left.\mathrm{CH}_{3}-8^{\prime}\right), 2.53$ (s, $\left.\mathrm{CH}_{3}-9^{\prime}\right), 3.97$ $\left(\mathrm{s}, \mathrm{OCH}_{3}\right) 12.48$ (s, 2-OH), 12.53 (s, 4-OH), 11.92 (s, 3'-OH); ${ }^{13} \mathrm{C}$ NMR (150 MHz, $\left.\mathrm{CDCl}_{3}\right): \delta 102.82(\mathrm{C}-1), 169.07$ (C-2), 108.53 (C-3), 167.47 (C-4), 112.84 (C-5), 152.42 (C-6), 169.68 (C-7), 193.82 (C-8), 25.56 (C-9), 151.97 (C-1'), 116.77 (C-2'), 162.86 (C-3'), 110.24 (C-4'), 139.85 (C-5'), 116.00 (C-6’), 172.18 [C-7'), 9.35 (C-8'), 24.01 (C-9'), 52.32 $\left(\mathrm{OCH}_{3}\right)$.

\section{RESULTS AND DISCUSSION}

Silica gel chromatography of the dichloromethane extract of $P$. austrocetratum has led to the isolation of zeorin (1) and atranorin (2). The structures of $\mathbf{1}$ and $\mathbf{2}$ were elucidated by extensive 1D and 2D NMR spectroscopy and confirmed by comparison of their NMR data with those reported in the literature for zeorin ${ }^{12-13}$ and atranorin, ${ }^{14}$ respectively.

Although there is no reported biological activity for P. austrocetratum, the compounds isolated from the plant were reported to possess diverse activities. Zeorin (1) and atranorin (2) have shown antidiabetic and antioxidant activities. ${ }^{15}$ Triterpene $\mathbf{1}$ also showed strong activity against bacteria and fungi. ${ }^{16}$ Depside 2 exhibited anti-proliferative action against malignant cell lines, ${ }^{17}$ antinociceptive effects ${ }^{18-19}$ and antibiotic action against $M$. aurum. ${ }^{20}$ It was found to inhibit leukotriene B4 synthesis in leukocytes, which might affect inflammatory processe ${ }^{21}$ and modulates the wound healing process. ${ }^{22}$

\section{CONCLUSION}

P. austrocetratum shares similar chemical characteristic with other Parmotrema species which yielded atranorin. This study highlights the first reported isolation of $\mathbf{1}$ from $P$. austrocetratum and the genus Parmotrema.

\section{ACKNOWLEDGEMENT}

A research grant from the De La Salle University Science Foundation through the URCO is gratefully acknowledged.

\section{CONFLICT OF INTEREST}

The authors declare no conflict of interest.

\section{ABBREVIATIONS}

$\mathrm{CH}_{2} \mathrm{Cl}_{2}$ : Dichloromethane; $\mathrm{CH}_{3} \mathrm{CN}$ : Acetonitrile; EtOAc: Ethyl acetate; $\mathbf{E t}_{2} \mathbf{O}$ : Diethyl ether.

\section{SUMMARY}

Chemical investigation of the dichloromethane extract of Parmotrema austrocetratum Elix and J. Johnst. has led to the isolation of a triterpene, zeorin (1) and a depside, atranorin (2). The structures of $\mathbf{1}$ and $\mathbf{2}$ were elucidated by $1 \mathrm{D}$ and 2D NMR spectroscopy and confirmed by comparison of their NMR data with literature data.

\section{REFERENCES}

1. Bawingan PA, Lardizaval MP, Rosuman PF, Fajardo WT, Azuelo A, Elix JA, et al. Philippine Species of Parmotrema (Ascomycota, Parmeliaceae). Philipp J Sci. 2017;146(2):145-58.

2. Feige GB. Etymologie der Wissenschaftlichen Gattungsnamen der Flechten. 1. Auflage. Essen. 1998;91.

3. Elix JA, Bawingan PA, Flores YG. A new species and further new records in the lichen family Parmeliaceae (Ascomycotina) from the Philippines. Mycotaxon. 2002;81:251-6.

4. Elix JA, Schumm F. A new species and new records in the lichen family Parmeliaceae Ascomycotina) from the Philippines. Mycotaxon. 2001;79:253-60.

5. Jabłonska A, Oset M, Kukwa M. The lichen family Parmeliaceae in Poland. I. The genus Parmotrema. Acta Mycologica. 2009;44(2):211-22.

6. Ukwa MK, Bach K, Sipman HJMS, Lakus AF. Thirty-six species of the lichen genus Parmotrema (Lecanorales, Ascomycota) new to Bolivia. Polish Bot J. 2012;57(1):243-57.

7. Benatti MN, Gernert M, Schmitt J. Parmotrema hydrium, a new species of Parmeliaceae in southeastern Brazil. Acta Bot Bras. 2013;27(4):810-4.

8. Rajan VP, Gunasekaran S, Ramanathan S, Murugaiyah V, Samsudin MW, Din LB. Biological activities of four Parmotrema species of Malaysian origin and their chemical constituents. J Appl Pharm Sci. 2016;6(8):036-043.

9. Ohmura Y, Kawachi M, Kasai F, Sugiura H, Ohtara K, Kon Y, et al. Morphology and chemistry of Parmotrema tinctorum (Parmeliaceae, Lichenized Ascomycota) transplanted into sites with different air pollution levels. Bull Natl Mus Nat Sci Ser B. 2009;35(2):91-8.

10. Micheletti AC, Beatriz A, Lima DPD, Honda NK, Pessoa CDÓ, Moraes MODLLV, Magalhães HIF, Carvalho NCP. Chemical constituents of Parmotrema lichexanthonicum Eliasaro and Adler - Isolation, structure modification and evaluation of antibiotic and cytotoxic activities. Química Nova. 2009;32(1):12-20.

11. Jayalal U, Divakar PK, Joshi S, Oh SO, Koh YJ, Hur JS. The lichen genus Parmotrema in South Korea. Mycobiol. 2013;41(1):25-36.

12. Marijana K, Branislav R, Slobodan S. Antimicrobial activity of the lichen Lecanora frustulosa and Parmeliopsis hyperopta and their divaricatic acid and zeorin constituents. Afr J Microbiol Res. 2010;4(9):885-90.

13. Mahato SB and Kundo AP. ${ }^{13} \mathrm{C}$ NMR spectra of pentacyclic triterpenoids - A compilation and some salient features. Phymchem. 1994;37(6):1517-75.

14. Ragasa CY, Tan MCS, Alba LDV, Shen CC. A depside from Frullania trichodes Mitt. Der Pharmacia Lettre. 2016;8(5):76-8. 
15. Thadhani VM, Karunaratne V. Potential of lichen compounds as antidiabetic agents with antioxidative properties: A review. Oxidative Medicine and Cellular Longevity. 2017;10. Article ID 2079697.

16. Branislav R, Marijana K, Slobodan S. Antimicrobial activity of some lichens and their components. Recent Advances in Clinical Medicine. 2010:279-86.

17. Kristmundsdottir T, Jonsdottir E, Ogmundsdottir HM, Ingolfsdottir K. Solubilization of poorly soluble lichen metabolites for biological testing on cell lines. Eur J Pharm Sci. 2005;24(5):539-43.

18. Melo MGD, Araujo AAS, Rocha CPL, Almeida EMSA, Siqueira RD, Bonjardim IR. Purification, physicochemical properties, thermal analysis and antinociceptive effect of atranorin extracted from Cladina kalbii. Biol Pharm Bull. 2008;31(10): $1977-80$
19. Maia MBdS, Silva NHD, Silva EFD, Catanho MTJ, Schuler ARP, Pereira EC Antinociceptive activity of crude extracts and atranorin obtained from the lichen Cladina dendroides (des Abb.) Ahti Acta Farm Bonaerense. 2002;21(4):259-64.

20. Ingolfsdottir K, Chung GA, Skulason VG, Gissurarson SR, Vilhelmsdottir M. Antimycobacterial activity of lichen metabolites in vitro. Eur $\mathrm{J}$ Pharm Sci. 1998;6(2):141-4

21. Kumar KC, Muller K. Lichen metabolites 1. Inhibitory action against leukotriene $\mathrm{B}_{4}$ biosynthesis by a non-redox mechanism. J Nat Prod. 1999;62(6):817-20.

22. Barreto RSS, Albuquerque-Júnior RLC, Pereira-Filho RN, Quintans JSS, Barreto AS, DeSantana JM, et al. Evaluation of wound healing activity of atranorin, a lichen secondary metabolite, on rodents. Rev Bras Farmacogn. 2013;23(2):310-9.

\section{GRAPHICAL ABSTRACT}
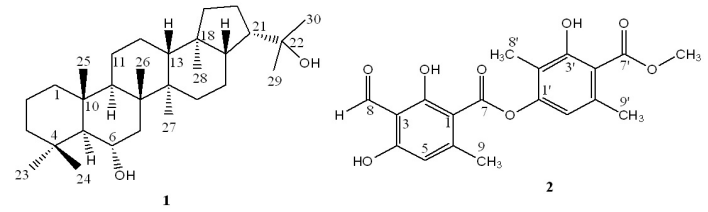

\section{SUMMARY}

- Chemical investigation of the dichloromethane extract of $P$. austrocetratum has led to the isolation of zeorin (1) and atranorin (2). This is the first report on the isolation of 1 from $P$. austrocetratum and the genus Parmotema.

\section{ABOUT AUTHORS}

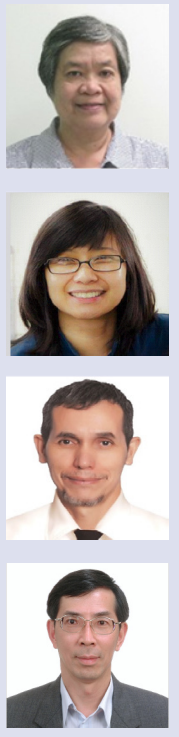

Consolacion Y. Ragasa: Full Professor 10 of the Chemistry Department and a University Fellow of De La Salle University - Manila, Philippines.

Maria Carmen S. Tan: Academic Service Faculty of De La Salle University - Manila, Philippines.

Virgilio C. Linis: Assistant Professorial Lecturer 5 of the Biology Department, College of Science, De La Salle University - Manila, Philippines.

Chien-Chang Shen: Associate Research Fellow in Division of Chinese Medicinal Chemistry, National Research Institute of Chinese Medicine, Ministry of Health and Welfare, Taiwan, ROC.

Cite this article: Ragasa CY, Tan MCS, Linis VC, Shen C. A Triterpene and a Depside from Parmotrema austrocetratum Elix and J. Johnst. Pharmacog J. 2018;10(6)Suppl:s27-s29. 